\title{
The role of basic psychological needs in the perception of job insecurity
}

\author{
Jasmina Knežević ${ }^{1}$ and Tatjana Krstić ${ }^{2}$ \\ ${ }^{1}$ High Vocational School for Teachers and Trainers, Subotica, Serbia \\ ${ }^{2}$ University of Novi Sad, Faculty of Medicine, Department of Psychology, Novi Sad, Serbia
}

[Received in May 2018; Similarity Check in July 2018; Accepted in February 2019]

\begin{abstract}
The aim of this study was to investigate whether satisfied basic psychological needs reduce the perception of threat generated by job insecurity, defined as self-assessment of the availability of the working role to its performers in the foreseeable future. The study included 310 participants employed in 24 companies, who completed the Perception of Job Insecurity Scale and Need Satisfaction Scale. The hypotheses were tested with multiple regression analyses. The results point to the importance of two basic needs - Autonomy and Competence - as factors that reduce the level of perceived job insecurity. This study broadens the understanding of personality resources as factors that moderate the perception of job insecurity and confirms the self-determination theory in the organisational context. Satisfying the needs for autonomy and competence can serve as a basis for interventions aimed at strengthening resilience to stress in employees.
\end{abstract}

KEY WORDS: autonomy; competence; moderating effect; perception of threat

Job insecurity can have negative consequences for both the employee and the employer and is one of the most significant sources of work-related stress (1). The stress arising from insecure employment adversely affects the physical and psychological wellbeing of employees (2), loyalty and commitment to the company and work satisfaction (3), and the general attitude toward the company and work-related behaviour (4). Job insecurity reflects a discrepancy between the experienced and preferred level of security (5). Davy, Kinicki, and Scheck (6) and van Vuuren (7) define job insecurity through expectations concerning the continuity of one's work situation or employment. Although there are multiple definitions of job insecurity, generally it can be regarded as a subjective phenomenon, which is based on individual perception and interpretation of the immediate work environment (5). The perception of job insecurity is determined by macro (socioeconomic context, organisational changes and culture) and micro-level factors (employee demographics and personality). Demographic variables that can affect the perception of job insecurity include gender (8), age (9-11), responsibility for the family (12), socioeconomic status $(10,13)$, education $(14,15)$, and support from friends and family (16). Personality factors that can affect this perception include self-esteem and optimism (17), emotional intelligence (18), self-regulatory mechanisms determined by the motivational orientation of personality (19), superior basic selfevaluations (20), locus of control (21), flexibility (22),

Corresponding author: Jasmina Knežević, $\mathrm{PhD}$, High Vocational School for Teachers and Trainers, Banijska 67, Subotica, Serbia,

E-mail:jasminaknezevic@vsovsu.rs psychological similarity of previous and current experience (23). Reports about the influence of the type of organisation on the perception of job insecurity disagree, however. While a Serbian study (24) did not establish a difference between public and private companies, European Foundation for the Improvement of Living and Working Conditions reported lower sense of insecurity in the public sector (25), but this difference melted since 2012. All these studies point to a more intense perception of job insecurity in employees who dislike organisational changes and job market trends or see organisational culture as unfair and restrictive in terms of participation in making decisions. A more intense perception of job insecurity was also found in employees who were older, male, less educated, without support from friends and family, of lower socioeconomic status, and with previous experience of job loss. Psychological traits that stand out in those with heightened perception of job insecurity are lack of optimism and sense of control, low self-confidence, and negative self-evaluation. Differences in perception between private and public sector employees seem to have diminished.

Basic psychological needs and the perception of job insecurity

According to the self-determination theory, satisfied basic psychological needs represent significant personality resources and the source of individual strength $(26,27)$. In keeping with this theory, work behaviour guided exclusively by fear of losing one's job is an example of unsatisfied basic psychological needs for autonomy, competence, and relatedness (28). Competence involves the sense of success 
in completing challenging tasks and achieving a desired goal. Autonomy implies a perception of choice and a sense of one's own initiative in behaviour and action, while the need for relatedness includes a sense of respect, care, and support. Satisfying basic psychological needs can change how one assesses their current psychological state, shape a stressful situation into a challenge rather than a threat (2932 ), lead to optimal motivation, greater psychological energy, and positive affect (33), and promote psychological wellbeing and various manifestations of psychological growth (34). Persons whose basic psychological needs are met are less prone to anxious reactions (35).

All this considered, basic psychological needs could provide a basis for creating different organisational interventions aimed at increasing resilience of employees and at reducing organisational stress caused by diminished job security. Accordingly, our study aimed to understand how satisfied basic psychological needs influence the perception of job insecurity. We started with the following hypotheses: better satisfaction of basic psychological needs in a working environment diminishes the sense of threat and powerlessness. We believe that these two are the crucial determinants of the perception of job insecurity.

\section{PARTICIPANTS AND METHODS}

\section{Participants}

The study included 310 volunteers - 144 male (46.5\%) and 166 female $(53.5 \%)$ - recruited by convenience sampling (Table 1). They were employed as workers $(\mathrm{N}=$ $247 ; 79.7 \%)$ or managers $(\mathrm{N}=63 ; 20.3 \%)$ by 24 companies in the north of Serbia different in size (15-78 employees), profile, structure, and ownership. All of them provided an informed written consent to participating in this study.

The study took place between January and March 2014. The questionnaires were distributed to groups by an investigator and were self-administered. In two cases the company psychologist distributed and collected the completed questionnaires. Of the 319 questionnaires, 310 were complete and statistically analysed. Participants who did not complete the questionnaires were excluded from analysis.

\section{Instruments and statistical analysis}

We used the Perception of Job Insecurity Scale (PJIS), which was designed earlier (36) and is based on the scales described elsewhere $(37,38)$. It has 22 items to assesses two affective and one cognitive dimension of job insecurity on a Likert-type scale (from 1 - completely disagree to 5 - completely agree). Higher total score indicates a higher sense of threat and powerlessness. The three factors of the perception of job insecurity yielded by factor analysis were intensity of threat, sense of powerlessness, and the likelihood of job loss. The first two are affective and pertain
Table 1 Sample demographics $(\mathrm{N}=310)$

\begin{tabular}{|c|c|c|c|}
\hline \multicolumn{4}{|c|}{ Descriptive characteristics of the sample } \\
\hline Category & & Number & $\%$ \\
\hline \multirow{2}{*}{ Gender } & Male & 144 & 46.5 \\
\hline & Female & 166 & 53.5 \\
\hline \multirow{3}{*}{ Age } & $20-35$ years & 115 & 37.1 \\
\hline & $36-45$ years & 93 & 30.0 \\
\hline & $46-65$ years & 102 & 32.9 \\
\hline \multirow{2}{*}{$\begin{array}{l}\text { Company } \\
\text { ownership }\end{array}$} & State & 130 & 41.9 \\
\hline & Private & 180 & 58.1 \\
\hline \multirow{2}{*}{$\begin{array}{l}\text { Position in the } \\
\text { company }\end{array}$} & Workers & 247 & 79.7 \\
\hline & Managers & 63 & 20.3 \\
\hline \multirow{4}{*}{$\begin{array}{l}\text { Level of } \\
\text { education }\end{array}$} & Primary school & 15 & 4.8 \\
\hline & High school & 186 & 60.0 \\
\hline & $\begin{array}{l}\text { College/ } \\
\text { university }\end{array}$ & 98 & 31.6 \\
\hline & $\begin{array}{c}\text { Master/doctoral } \\
\text { degree }\end{array}$ & 11 & 3.5 \\
\hline \multirow{4}{*}{ Marital status } & Married & 181 & 58.4 \\
\hline & Single & 98 & 31.6 \\
\hline & Divorced & 23 & 7.4 \\
\hline & Widow/er & 8 & 2.6 \\
\hline \multirow{3}{*}{$\begin{array}{l}\text { Socioeconomic } \\
\text { status }\end{array}$} & Below average & 46 & 14.8 \\
\hline & Average & 226 & 72.9 \\
\hline & Above average & 38 & 12.3 \\
\hline \multirow{2}{*}{$\begin{array}{l}\text { Previous } \\
\text { experience of job } \\
\text { loss }\end{array}$} & Yes & 141 & 45.5 \\
\hline & No & 169 & 54.5 \\
\hline
\end{tabular}

to subjectively evaluated worry over job loss and a sense of not being able to prevent it. The likelihood of job loss is a cognitive factor expressed as assessment of job loss probability.

For the purposes of this study, principal component analysis identified four factors with square root values higher than 1, while the Scree test identified three factors. These were then subjected to promax rotation, which provided the best possible representation of data and explained $55.42 \%$ of the total variance.

The component matrix showed that most items grouped around the three isolated factors, but two items (PJIS 18 and 9) had multiple saturations. We therefore removed them and repeated factor analysis. This created three subscales: intensity of threat - 11 items, likelihood of job loss - four items, and sense of powerlessness - five items. Sense of powerlessness had a slightly lower reliability $(\alpha=0.656)$ than intensity of threat $(\alpha=0.926)$ and likelihood of job loss $(\alpha=0.812)$. The total scale showed good reliability $(\alpha=0.903)$. However, since the study investigated the relationship between the satisfaction of basic psychological needs in the working environment and the affective components of job insecurity perception, the cognitive dimension (likelihood of job loss) was left out of any further statistical analysis. 
The Need Satisfaction Scale (NSS) consists of 21 items to be answered on a five-point Likert-type scale (from 1 completely disagree to 5 - completely agree). Higher score corresponds to a higher level of satisfaction of the basic psychological needs. Mladenović (39) translated and adapted this scale from the original developed by Deci et al. (40) for the purposes of her doctoral thesis. The scale assesses a personal sense of autonomy, competence, and relatedness of an employee.

Factor analysis identified three factors that explained $46.9 \%$ of the total variance and included 21 items. Fifteen items grouped around these three components in the composition matrix, while six items had multiple saturations. Repeated factor analysis provided a better factor structure, but it still had three items with multiple saturations, which had to be excluded from further analysis. Eventually, three subscales were formed: autonomy (three items), competence (four items), and relatedness (four items). Because as many as ten items were removed from this scale, the reliability of subscales was lower than in the PJIS: $\alpha=0.615, \alpha=0.548$, and $\alpha=0.807$, respectively.

\section{RESULTS AND DISCUSSION}

Table 2 shows the basic descriptive statistics for all the variables included in this study. None deviated significantly from normal distribution (see the index of skewness and kurtosis, which are both within the -1 to +1 range, except for intensity of threat kurtosis, which is close to the critical value).

Table 3 shows that the correlations between all variables were statistically significant.

Multiple regression analysis using the basic psychological needs as predictors and intensity of threat as the criterion variable singled out two significant predictors: autonomy and competence (Table 4). Higher self-perceived autonomy and competence entailed lower threat intensity, which partly confirmed our first hypothesis that basic need satisfaction in the working environment would diminish the perception of job insecurity.

Multiple regression analysis using the basic psychological needs as the predictor variables and sense of powerlessness as the criterion variable singled out autonomy as the only significant predictor. An increase in perceived autonomy entailed a decrease in the sense of powerlessness (Table 5), which also partly confirmed the second hypothesis that basic need satisfaction diminishes the sense of powerlessness.

These findings are in accordance with previous studies of the relationship between job insecurity and psychological wellbeing in the working context $(41,42)$. Research also suggests that the context which promotes basic need satisfaction contributes to a person's vitality and strength of the self, which, in turn, contribute to improved selfconfidence, mental health, and better general psychological wellbeing (43). It is justified to assume that these psychological qualities alleviate the sense of threat. Perceived appreciation of competences and sense of efficacy (mastership) are likely to be transferred onto getting to grips with job insecurity and decreasing the sense of powerlessness caused by it.

Generally, we can conclude that self-perceived autonomy and competence constitute psychological resources which contribute to the psychological empowerment of the employee in a demanding situation such as job insecurity, which is supported by previous studies $(44,45)$. These resources can encourage one to observe a threat as a challenge and use active and efficient coping strategies against stress at the workplace (20).

In the context of our own research, we can conclude that satisfaction of the need for autonomy stands out as the most important factor in diminishing the sense of job insecurity. The need for autonomy can be developmentally more relevant in the perception of threat in the working environment than other needs, which is in line with the self-determination theory, as it places the need for autonomy on top of all life domains (46).

Our study contributes to current research of organisational stress and psychological functioning of employees facing a threat of job loss by confirming the results of previous studies (47) that satisfied basic psychological needs provide an important psychological resource at work and allow employees to channel their energy and behaviour in constructive ways and be less prone to emotional exhaustion. To the best of our knowledge, this is the first study on perception of job insecurity in Serbia

Table 2 Descriptive statistics for the variables used in the study

\begin{tabular}{llllllll}
\hline \multicolumn{1}{l}{$\begin{array}{l}\text { Variable } \\
\text { Perception of Job Insecurity Scale }\end{array}$} & & & & & & \\
\hline
\end{tabular}

the number of items for each variable is given in brackets 
Table 3 Correlations between variables

\begin{tabular}{lccccc}
\hline Variable & Powerlessness & Threat intensity & Relatedness & Autonomy & Competence \\
\hline Powerlessness & 1 & & & & \\
\hline Threat intensity & $0.510^{*}$ & 1 & & & \\
\hline Relatedness & $-0.241^{* *}$ & $-0.175^{* *}$ & 1 & & \\
\hline Autonomy & $-0.296^{* *}$ & $-0.440^{* *}$ & $0.494^{* *}$ & 1 & \\
\hline Competence & $-0.151^{*}$ & $-0.370^{* *}$ & $0.450^{* *}$ & $0.588^{* *}$ & 1 \\
\hline
\end{tabular}

$* \mathrm{p}<0.05 ; * * \mathrm{p}<0.01$

and the first to point out the importance of satisfied basic psychological needs in creating a relatively stable basis for resilience against work-related stress.

\section{Implications for practice}

Our findings identify two factors that meaningful organisational interventions should target: the satisfaction of the needs for autonomy and competence. Employee autonomy can be increased by stimulating their participation in the organisation through interventions such as sharing information, making situations predictable, providing meaningful explanations for work demands, showing respect for the employees' opinions, and minimising work pressure in the form of strict control or strong expectations (48).

The sense of competence, in turn, can be boosted by increasing the level of control, creating a sense of efficacy and productiveness, and providing feedback. Feedback is a powerful motivational and educational tool, if provided properly. It boosts the sense of self-worth and provides ways of improvement.

\section{Implications for research}

Self-assessment of stress at work is influenced by dispositional mood factors (49). Furthermore, certain personality variables, such as optimism and positive affect, can play an important role with regard to the assessment of job insecurity (41). In that respect, future research should control emotional and personality variables. Likewise, considering the drop in motivation caused by the deprivation of a wide spectrum of needs in the situation of job insecurity, it would be well advised that future studies should include motivational variables, such as the employees' goals, work engagement, commitment to the company, and work centralisation. Further research should explore in more depth the causal relations between the satisfaction of basic psychological needs and the perception of job insecurity. New variables - whether adverse or beneficial - need to be identified and included for us to better understand individual differences in the perception of job insecurity and the

Table 4 Contributions of predictors in predicting threat intensity

\begin{tabular}{lccc}
\hline Predictors & $\boldsymbol{\beta}$ & $\mathbf{F}\left(\boldsymbol{d} \boldsymbol{f}_{1}, \boldsymbol{d} \boldsymbol{f}_{2}\right)$ & $\mathbf{R}^{2}$ \\
\hline Autonomy & $-0.374 * *$ & & \\
\hline Relatedness & 0.097 & $21.26^{* *}(3,227)$ & $22 \%$ \\
\hline Competence & $-0.194^{*}$ & & \\
\hline${ }^{*} \mathrm{p}<0.05 ; * \mathrm{p}<0.01$ & & &
\end{tabular}

mechanisms that lie at the heart of this phenomenon. Besides the individual approach, future research should focus on the contextual/organisational level. A supportive organisational culture could enhance employees' wellbeing.

Designing future research in this way should be instrumental to companies in understanding their employees and creating a better working environment.

\section{Limitations}

The limitations of our study are primarily related to its design. Self-evaluations of work-related stress can be affected by dispositional mood (49) and run the risk of the so called "common method bias", which can inflate the correlations between dimensions.

Another limitation concerns self-evaluation of the satisfaction of basic psychological needs. It is more likely to be linked to need-related motives than satisfaction of the need itself (e.g. the need for relatedness can be satisfied by belonging to a certain group, but being a group member can also satisfy other similar motives). In other words, self-evaluation may leave out needs of which persons are not fully aware. To overcome this limitation, the assessment of need satisfaction should also include sources other than

Table 5 Contributions of predictors in predicting the sense of powerlessness

\begin{tabular}{lccc}
\hline $\begin{array}{l}\text { Predictor } \\
\text { variables }\end{array}$ & $\boldsymbol{\beta}$ & $\mathbf{F}\left(\boldsymbol{d} \boldsymbol{f}_{1}, \boldsymbol{d f}_{2}\right)$ & $\mathbf{R}^{2}$ \\
\hline Autonomy & $-0.267 * *$ & & \\
\hline Relatedness & -0.140 & $8.62 * *(3,227)$ & $10 \%$ \\
\hline Competence & 0.069 & & \\
\hline$* \mathrm{p}<0.05 ; * * \mathrm{p}<0.01$ & & &
\end{tabular}

the questionnaire (e.g. employer's statement or a participant's journal recording their observations about the working environment)

Another limitation is the possibility of reverse causality. The employees' perception of job insecurity could have affected their assessment of the basic need satisfaction. This issue can be addressed by a longitudinal research that would establish long-term effects of basic need satisfaction after controlling for other important factors, such as basic psychological needs at baseline as well as mood and personality factors.

Finally, samples from single companies were small and uneven, and future research could benefit from a larger and evenly distributed sample across companies. 


\section{REFERENCES}

1. De Cuyper N, Bernhard-Oettel C, Berntson E, De Witte H, Alarco B. Employablity and employee's well-being: Mediation by job insecurity. Appl Psychol 2008;57:488-509. doi: 10.1111/j.1464-0597.2008.00332.x

2. Bertaux N, Queneau, H. The social economics of job security Forum Soc Econ 2002;32:1-19. doi: 10.1007/BF02747262

3. De Witte H, Näswall K. "Objective" vs "Subjective" job insecurity: Consequences of temporary work for job satisfaction and organizational commitment in four European countries. Econ Ind Democracy 2003;24:149-88. doi: 10.1177/0143831X03024002002

4. Sverke M, Hellgren J, Näswall K. No security: A metaanalysis and review of job insecurity and its consequences. J Occup Health Psychol 2002;7:242-64. doi: 10.1037/10768998.7.3.242

5. Hartley J, Jacobson D, Klandermans B, Van Vuuren T. Job Insecurity: Coping with Jobs at Risk. London: Sage Publications Ltd.; 1991.

6. Davy JA, Kinicki AJ, Scheck CL. A test of job security's direct and mediated effects on withdrawal cognitions. J Organ Behav 1997;18:323-49. doi: 10.1002/(SICI)1099. 1379(199707)18:4<323::AID-JOB801>3.0.CO;2-\%23

7. Van Vuuren T. Met ontslag bedreigd: Werknemers in onzekerheid over hun arbeidsplaats bij veranderingen in de organisatie [Threats of job loss: Employees workplace uncertainty during organizational change, in Dutch]. Amsterdam: VU Uitgeverij; 1990

8. Clark CL, Sacks MP. A view from below: Industrial restructuring and women's employment at four Russian enterprises. Communist and Post-Communist Stud 2004;37:523-45. doi: 10.1016/j.postcomstud.2004.09.003

9. Mohr GB. The changing significance of different stressors after the announcement of bankruptcy: A longitudinal investigation with special emphasis on job insecurity. J Organ Behav 2000;21:337-59. doi: 10.1002/(SICI)1099. 1379(200005)21:3<337::AID-JOB18>3.0.CO;2-G

10. Sverke M, Hellgren J, Näswall K, Chirumbolo A, De Witte $\mathrm{H}$, Goslinga S. Job Insecurity and Union Membership: European Unions in the Wake of Flexible Production. Brussels: P.I.E.-Peter Lang S.A.; 2004.

11. Fullerton AS, Wallace M. Traversing the flexible turn: US workers' perceptions of job security, 1977-2002. Soc Sci Res 2007;36:201-21. doi: 10.1016/j.ssresearch.2005.09.005

12. Lim VKG. Job insecurity and its outcomes: Moderating effects of work-based and nonwork-based social support. Human Relations 1996;49:171-94. doi: $10.1177 / 001872679604900203$

13. Mauno S, Kinnunen U. Perceived job insecurity among dualearner couples: Do its antecendents vary according to gender, economic sector and the measure used? J Occup Organ Psychol 2002;75:295-314. doi: 10.1348/096317902320369721

14. Kinnunen U, Nätti J. Job Insecurity in Finland: Antecedents and consequences. Eur J Work Organ Psychol 1994;4:297321. doi: $10.1080 / 13594329408410490$

15. Dominitz J, Manski CF. Perceptions of economic insecurity: Evidence from the survey of economic expectations. Public Opin Q 1997;61:261-87. doi: 10.3386/w5690

16. Armstrong-Stassen M. Production workers' reactions to a plant closing: The role of transfer, stress and support. Anxiety
Stress Coping 1993;6:201-14. doi: $10.1080 / 10615809308248380$

17. Makikangas A, Kinnunen U. Psychosocial work stressors and well-being: Self-esteem and optimism as moderators in a one-year longitudinal sample. Pers Individ Dif 2003;35:53757. doi: 10.1016/S0191-8869(02)00217-9

18. Jordan PJ, Ashkanasy NM, Hartel CEJ. Emotional intelligence as a moderator of emotional and behavioral reactions to job insecurity. Acad Manage Rev 2002;27:36172. doi: $10.2307 / 4134384$

19. Ntoumanis N, Edmunds J, Duda JL. Understanding the coping process from a self-determination theory perspective. Br J Health Psychol 2009;14:249-60. doi: 10.1348/135910708X349352

20. Kammeyer-Mueller JD, Judge TA, Scott BA. The role of core self-evaluations in the coping process. J Appl Psychol 2009;94:177-95. doi: 10.1037/a0013214

21. Orpen C. The effects of self-esteem and personal control on the relationship between job insecurity and psychological well-being. Soc Behav Pers 1994;22:53-6. doi: 10.2224/ sbp.1994.22.1.53

22. Otto K, Dette-Hagenmeyer DE, Dalbert C. Occupational mobility in members of the labor force: Explaining the willingness to change occupations. J Career Dev 2010;36:26288. doi: $10.1177 / 0894845309345842$

23. Green F. The rise and decline of job insecurity. Department of Economics Discussion Paper. No. 03, 05. Canterbury: University of Kent; 2003.

24. Knežević J, Mitrić Aćimović D. Psihološki aspekt savremene srpske organizacije: trendovi, problemi i rešenja [Psychological aspect of contemporary Serbian organization: trends, problems and solutions, in Serbian]. Beograd: Centar za primenjenu psihologiju; 2017.

25. European Foundation for the Improvement of Living and Working Conditions. Trends in skills requirements and work - related issues [displayed 20 September 2018]. Available at http://www.eurofound.europa.eu/eiro/surveyreports/ uk1312029d/uk1312029d.pdf

26. Ryan MR, Deci EL. Intrinsic and extrinsic motivation: Classic definitions and new directions. Contemp Educ Psychol 2000;25:54-67. doi: 10.1006/ceps.1999.1020

27. Ryan RM, Deci EL. Overview of self-determination theory: An organismic dialectical perspective. In: Ryan RM, Deci EL, editors. Handbook of self-determination research. Rochester, New York: The University of Rochester Press; 2002. p. 6-9.

28. Vander Elst T, Van den Broeck A, De Witte H, De Cuyper $\mathrm{N}$. The mediating role of frustration of psychological needs in the relationship between job insecurity and work-related well-being. Work Stress 2012;26:252-71. doi: 10.1080/02678373.2012.703900

29. Blascovich J, Mendes WB, Tomaka J, Salomon K, Seery M. The robust nature of the biopsychosocial model challenge and threat: A reply to Wright and Kirby. Pers Soc Psychol Rev 2003;7:234-43. doi: 10.1207/S15327957PSPR0703_03

30. Hodgins HS. Motivation, threshold for threat, and quieting the ego. In: Wayment HA, Bauer JJ, editors. Transcending self-interest: Psychological explorations of the quiet ego. Washington (DC): American Psychological Association; 2008. p. 117-24

31. Hodgins SH, Knee RC. The integrating self and conscious experience. In: Deci EL, Ryan RM, editors. Handbook of 
self-determination research. Rochester (NY): The University of Rochester Press; 2002. p. 87-100.

32. Skinner E, Edge K. Self-determination, coping, and development. In: Deci EL, Ryan RM, editors. Handbook of self-determination research. Rochester (NY): University of Rochester Press; 2002. p. 297-337.

33. Van den Broek A, Vansteenkiste M, De Witte H, Lens W. Explaining the relationships between job characteristics, burnout and engagement: The role of basic psychological need satisfaction. Work Stress 2008;22:277-94. doi: 10.1080/02678370802393672

34. Vansteenkiste M, Ryan RM. On psychological growth and vulnerability: Basic psychological need satisfaction and need frustration as a unifying principle. J Psychother Integr 2013;23:263-80. doi: 10.1037/a0032359

35. Baard PP, Deci EL, Ryan RM. Intrinsic need satisfaction: A motivational basis of performance and well-being in two work settings. J Appl Soc Psychol 2004;34:2045-68. doi: 10.1111/j.1559-1816.2004.tb02690.x

36. Knežević J, Majstorović N. Merenje percepcije nestabilnosti zaposlenja: konstrukcija i validacija Skale percepcije nestabilnosti zaposlenja [Measuring the perception of job instability: the construction and validation of the Scale of Perceptions of Job Instability, in Serbian]. Novi Sad: Filozofski fakultet, Univerzitet u Novom Sadu; 2013.

37. Ashford SJ, Lee C. Bobko P. Content, cause and consequences of job insecurity: A theory-based measure and substantive test. Acad Manage J 1989;32:803-29. doi: 10.5465/256569

38. Isaksson K, Hellgren J, Pettersson P. Strukturomvandling inom svensk detaljhandel: Uppföljning av omorganization och personalminskning i KF/KDAB [Structural transformation in Swedish retail trade: Follow-up of a reorganisation and layoff in KF/KDAB, in Swedish]. Stockholm: Stockholm University; 1998.

39. Mladenović M. Uticaj globalne motivacione orijentacije i percepcije bazičnih psihičkih potreba na motivaciju za rad [Impact of global motivational orientation and perception of basic psychological needs on motivation for work, in Serbian] [PhD thesis]. Beograd: Filozofski fakultet, Univerzitet u Beogradu; 2009.
40. Deci EL, Ryan RM, Gagne' M, Leone DR, Usunov J, Kornazheva BP. Need satisfaction, motivation, and wellbeing in the work organizations of a former eastern bloc country. Pers Soc Psychol Bull 2001;27:930-42. doi: 10.1177/0146167201278002

41. Greenhalgh L, Rosenblatt Z. Job insecurity: Toward conceptual clarity. Acad Manage Rev 1984;9:438-48. doi: 10.5465/AMR.1984.4279673

42. Sverke M, Hellgren J. The nature of job insecurity: Understanding employment insecurity on the brink of a new millennium. Appl Psychol 2002;51:23-42. doi: 10.1111/14640597.0077z

43. Ryan RM, Frederick C. On energy, personality and health: Subjective vitality as a dynamic reflection of well-being. J Pers 1997;65:529-65. doi: 10.1111/j.1467-6494.1997. tb00326.x

44. Cho J, Laschinger HKS, Wong C. Workplace empowerment, work engagement and organizational commitment of new graduate nurses. Nurs Leadersh (Tor Ont) 2006;19:43-60. doi: $10.12927 / \mathrm{cjnl} .2006 .18368$

45. Best RG, Stapleton LM, Downey RG. Core self-evaluations and job burnout: The test of alternative models. J Occup Health Psychol 2005;10:441-51. doi: 10.1037/10768998.10.4.441

46. Deci E, Ryan R. Self-determination theory and the facilitation of intrinsic motivation, social development, and well-being. Am Psychol 2000;55:68-78. doi: 10.1037/0003-066X.55.1.68

47. Fernet C, Austina S, Vallerand RJ. The effects of work motivation on employee exhaustion and commitment: An extension of the JD-R model. Work Stress 2012;26:213-29. doi: $10.1080 / 02678373.2012 .713202$

48. Deci EL, Eghrari H, Patrick BC, Leone D. Facilitating internalization: The self-determination theory perspective. J Pers 1994;62:119-42. doi: 10.1111/j.1467-6494.1994. tb00797.x

49. Hellgren J, Sverke M, Isaksson K. A two-dimensional approach to job insecurity: Consequences for employee attitudes and well-being. Eur J Work Organ Psychol 1999;8:179-95. doi: 10.1080/135943299398311

\section{Uloga osnovnih psiholoških potreba u percepciji nesigurnosti posla}

Cilj ovoga istraživanja je bio ispitati smanjuju li zadovoljene psihološke potrebe percepciju prijetnje koja proizlazi iz nesigurnosti zaposlenja, koje je određeno samoprocjenom dostupnosti radne uloge u budućnosti. U istraživanju je sudjelovalo 310 zaposlenika u 24 tvrtke, koji su popunjavali Ljestvicu percepcije nesigurnosti posla i Ljestvicu zadovoljenosti potreba. Hipoteze su provjeravane višestrukim regresijskim analizama. Rezultati su pokazali značaj dviju osnovnih potreba - autonomije i kompetentnosti - kao čimbenika koji smanjuju razinu opažene nesigurnosti posla. Proširujući razumijevanje resursa ličnosti kao čimbenika koji moderiraju percepciju nesigurnosti posla, ovo istraživanje predstavlja primjenu teorije samodeterminacije u organizacijskom kontekstu. Zadovoljenje potreba za autonomijom i kompetencijom može poslužiti kao osnova za intervencije čiji je cilj jačanje otpornosti na stres u zaposlenih osoba. 